\title{
Phytochemical and In-Vitro Evaluation of Anti-oxidant Activity of Mansoa alliacea Leaves
}

\section{SK Ameenabee ${ }^{1}$, A Lakshmana Rao ${ }^{2}$, P Suguna Rani ${ }^{3}$, T Sandhya ${ }^{4}$, N Teja ${ }^{5 *}$, G Ashu ${ }^{5}$, V Bhavya Naga Vani ${ }^{6}$, CH Purna Durganjali ${ }^{6}$ and N Pavani ${ }^{7}$}

${ }^{1}$ Associate Professor, Department of Pharmacology, V.V. Institute of

Pharmaceutical Sciences, Gudlavalleru, India

${ }^{2}$ Professor and Principal, Department of Pharmaceutical Analysis, V.V. Institute of

Pharmaceutical Sciences, Gudlavalleru, India

${ }^{3}$ Department of Pharmacology, Sri Venkateswara University of Pharmaceutical

Sciences, Tirupathi, India

${ }^{4}$ Department of Pharmacology, Institute of Pharmaceutical Technology, Sri

Padmavathi Mahila Viswavidhyalayam, Tirupathi, India

${ }^{5}$ Department of Pharmaceutics, V.V. Institute of Pharmaceutical Sciences,

Gudlavalleru, India

${ }^{6}$ Department of Pharmaceutical Analysis, V.V. Institute of Pharmaceutical

Sciences, Gudlavalleru, India

${ }^{7}$ Department of Pharmacy, V.V. Institute of Pharmaceutical Sciences, Guldavalleru, India

*Corresponding Author: N Teja, Department of Pharmaceutics, V.V. Institute of Pharmaceutical Sciences, Gudlavalleru, India.
Received: August 13, 2020

Published: September 10, 2020

(C) All rights are reserved by $\mathbf{N}$ Teja., et al.

\begin{abstract}
Mansoa alliacea Lam. (Family: Bignoniaceae) is a native plant from Amazonian basin in South America. Plant derivatives are used as an anti-inflammatory, anti-oxidant, antiseptic and anti-bacterial. The study was aimed to determine the pharmacognostic and phytochemicals present in Mansoa alliacea. Micro and Organoleptic characteristics of fresh and dried leaf samples had been examined. Physicochemical chemical variables have been done by using WHO suggested variables, preliminary phytochemical of leaf sample had been performed to identify the presence of alkaloids, flavonoids, tannins and phenols, and quinones using the ethanolic extract of the leaves of M. alliacea.
\end{abstract}

Keywords: M. alliacea; Alkaloids; Flavonoids; Tannins

\section{Introduction}

According to the World Health Organization [1], about 65\% - $80 \%$ of the population in developing countries use medicinal plants to treat their health benefits. Mansoa alliaceae belongs to the Bignoniaceae family, which is used extensively by many of the indigenous peoples of Amazonia. It is commonly referred to as garlic and Ajossacha [2]. So far, phytochemical studies have shown that plants alkaloids, flavonoids, steroids, tannins and phenols are structurally diverse chemicals. Of modern herbal medicine in S, the plant has also become a popular treatment. America where arthritis, rheumatists, body aches and pain and muscle aches, injuries and pain are widely used. Blooms and flowers are made up of anti 
- inflammatory, antioxidant [3] plant antioxidants and anti - bacterial steroids, beta sitosterol, stigmasterol, daucosterol and fucosterol. The Mansoa (Bignoniaceae) family is a source of compounds containing organosulfur [5]. M. Alliacea used for reproductive organs, renal distress, dizziness, epilepsy, sickening cell disease, depression, metabolism, skin grievance, leprosy, impetigo, helminthic infections, foot athlete, tumors. In this study, we are making an effort to standardize M. The alliacea field was conducted for the study of leaf morphological, anatomical, physicochemical and preliminary research.

\section{Materials and Methods}

\section{Identification and collection of plant material}

The whole plant of Mansoa alliacea was collected from the surrounding area of Machilipatnam, Andhra Pradesh, India. These plants were identified and authenticated in the Department of Botany, Hindu College, Machilipatnam. The leaves are cleaned and shade dried under room temperature for one week. Then leaves are crushed to powder. The powdered sample was stored in an airtight waterproof container protected from direct sunlight and heat until the powdered sample is used for the extraction process.

\section{Preparation of extracts}

The powdered material of Mansoa alliacea (leaves) were extracted for 24 hrs with laboratory alcohol(ethanol) in soxhlet apparatus $[7,8]$. The extracts were concentrated to dryness till free from the solvents.

\section{Phytochemical analysis}

Phytochemical analysis [9] of the extract was carried out for the presence of saponins, tannins, flavonoids, alkaloids, glycosides, steroids, carbohydrates, proteins and phenols by different methods.

\section{Hydrogen peroxide scavenging activity}

The ability of hydrogen peroxide extracts to scavenge was based on the Ruch11 method. In a phosphate buffer ( $\mathrm{pH} 7.4)$, a solution of hydrogen peroxide ( $40 \mathrm{mM}$ ) has been made. The hydrogen peroxide concentration was determined by spectrophotometer absorption at $230 \mathrm{~nm}$. Hydrogen peroxide (0.6 ml, $40 \mathrm{mM}$ ) was blended with extracts. After 10 minutes, the absorbance of hydrogen peroxide was determined against a blank phosphate buffer solution without hydrogen peroxide. The amount of hydrogen peroxide scavenging calculated as follows by extracts and regular compounds.
Scavenging activity $(\%)=[($ Abscontrol - Abssample $)] /($ Abscontrol)] x 100

\section{Reducing power assay}

The reduction strength was calculated by the Oyaizu12 cycle. Substances with a reduction potential react to potassium ferricyanide $\left(\mathrm{Fe}^{3+}\right)$ as potassium ferrocyanide $\left(\mathrm{Fe}^{2+}\right)$, which reacts with ferrous chloride to form a ferrous ferrous system with a maximum absorption of $700 \mathrm{~nm}$. Mixed with a phosphate buffer $(2.5 \mathrm{ml})$ and potassium ferricianide $(2.5 \mathrm{ml})$, one liter of the test solution. The mixture was incubated for 20 minutes at $50^{\circ} \mathrm{C}$. The mixture has been applied with trichloroacetic acid ( $2.5 \mathrm{ml}$ ), which was then centrifuged at $3000 \mathrm{rpm}$ for 10 minutes. The top layer of fluid (2.5 $\mathrm{ml})$ was mixed to distilled water $(2.5 \mathrm{ml})$ and a freshly prepared solution of ferric chloride $(0.5 \mathrm{ml})$. At $700 \mathrm{~nm}$, the absorbance was measured. The typical use was ascorbic acid (20 $\mu \mathrm{g} / \mathrm{ml})$. By adding a standard or test content, a blank was prepared. Increased reaction mix absorption indicates an increase in power reduction.

\section{Phosphomolybdenum method}

The complete anti - oxidant capacity test is a spectroscopic way to quantify anti - oxidant ability by creating phosphomolybdenum complex 13 . In conjunction with $1 \mathrm{ml}$ of reagent $(0.6 \mathrm{M}$ Sulfuric Acid, $28 \mathrm{mM}$ Sodium and $4 \mathrm{mM}$ ammonium molybdate), take $0.1 \mathrm{ml}$ of the sample solution. The tube is sealed and incubated at $95^{\circ} \mathrm{C}$ for 90 minutes in a boiling water bath. The absorbance of the solution is measured at $695 \mathrm{~nm}$ against blank in UV after the sample has cooled to room temperature. Spectrometer. Spectrophotometer.

\section{Results and Discussion}

Preliminary phytochemical analysis

Phytochemical test of $M$. alliacea ethanol extract was done. The existence of saponins, flavonoids, alkaloids, steroids, sugars, and phenolic compounds was shown in alliacea leaves (Table 1). As the anti oxidant function is induced by phenolic compounds and the flavonoids, the amounts present in the extract are high, indicating good antioxidant activity. The phenolic and flavonoid scavenging potential is largely attributed to the existence of hydroxyl groups. The presence of phenolic compounds14 in the plant has led to its antioxidant activity and thus its effectiveness as a medication. Flavonoids have been shown to have the impact on membrane permeability and membrane bond enzymes, including ATPase and phospholipase A2, inhibited. 


\begin{tabular}{|l|c|c|c|c|}
\hline \multirow{2}{*}{ Phytoconstituents } & Chemical test & Aqueous extract & Alcohol extract & $\begin{array}{c}\text { Chloroform } \\
\text { extract }\end{array}$ \\
\hline \multirow{3}{*}{ Flavonoids } & Shinoda Test & + & + & - \\
\cline { 2 - 5 } & Zn + HCl Test & + & + & - \\
\cline { 2 - 5 } & Lead acetate Test & + & + & - \\
\hline \multirow{3}{*}{ Alkaloids } & Dragandroff's test & + & - & - \\
\cline { 2 - 5 } & Wagner Test & - & - & - \\
\cline { 2 - 5 } & Hager's Test & - & + & - \\
\hline Tannins and Phenols & FeCl Test & + & - & - \\
\hline Saponins & Foaming Test & - & - & - \\
\hline Steroids & Salkowski test & + & + & - \\
\hline Carbohydrates & Molisch test & + & + & - \\
\hline Glycoside & Keller-Killani Test & + & + & - \\
\hline Amino acids & Ninhydrin Test & + & + & + \\
\hline Proteins & Biuret Test & + & + & + \\
\hline
\end{tabular}

Table 1: Phytoconstituents of Mansoa alliacea leaf powder.

\section{Phosphomolybdenum method}

Total anti-oxidant capacity assay is a spectroscopic method for the quantitative determination of anti-oxidant capacity, through the formation of phosphomolybdenum complex [15]. Take $0.1 \mathrm{ml}$ of the sample solution is combined with $1 \mathrm{ml}$ of reagent $(0.6 \mathrm{M}$ sulfuric acid, $28 \mathrm{mM}$ sodium phosphate and $4 \mathrm{mM}$ ammonium molybdate). The tube is capped and incubated in a boiling water bath at $95^{\circ} \mathrm{C}$ for 90 minutes. After cooling the sample to room temperature, the absorbance of the solution is measured at $695 \mathrm{~nm}$ against blank in U.V. spectrophotometer.

\section{Hydrogen peroxide scavenging activity}

Hydrogen peroxide scavenging activity of the ethanol extract and standard was given in table 2 and figure 1. Mansoa alliacea ethanolic extract caused a strong dose-dependent inhibition of hydrogen peroxide. At a concentration of 10, 25, 50, 75 and $100 \mu \mathrm{g} / \mathrm{ml}$ of the extract the scavenging percentage was $26.26,44.85,48.94$, 60.50 and 67.54 respectively.

\begin{tabular}{|l|c|c|}
\hline Concentration & $\begin{array}{c}\text { Absorbance at } \\
\text { 230nm }\end{array}$ & Percent inhibition \\
\hline Control & $0.0946 \pm 0.0004$ & - \\
\hline Standard & $0.1850 \pm 0.0007$ & 96 \\
\hline 10 & $0.1550 \pm 0.0002$ & 28.67 \\
\hline 25 & $0.1419 \pm 0.0003$ & 43.91 \\
\hline 50 & $0.1420 \pm 0.0016$ & 48.99 \\
\hline 75 & $0.1510 \pm 0.0007$ & 62.4 \\
\hline 100 & $0.1597 \pm 0.0009$ & 69.58 \\
\hline
\end{tabular}

Table 2: Anti-oxidant activity of $M$. alliacea leaves by $\mathrm{H}_{2} \mathrm{O}_{2}$ scavenging activity.

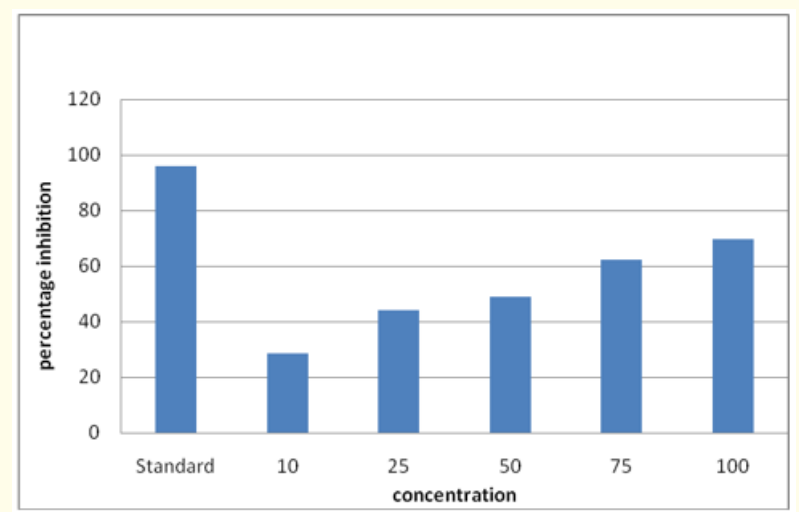

Figure 1

\section{Reducing power assay}

The reducing power of the extract compared to ascorbic acid is shown in table 3. In the reductive ability measurement, $\mathrm{Fe}^{3+}-\mathrm{Fe}^{2+}$ transformation in the presence of extract sample was investigated. Reducing power assay is a convenient and rapid screening method for measuring the anti-oxidant potential. In this investigation, table 3 and figure 2 shows the reductive capabilities of ethanolic extract of Mansoa alliacea when compared to the standard ascorbic acid. The reducing power increased significantly with increasing concentration of the extract. At 10, 25, 50, 75 and $100 \mu \mathrm{g} / \mathrm{ml}$ the reducing power was $30.26,36.54,48.09,56.39$ and 62.55 respectively. 


\begin{tabular}{|l|c|c|}
\hline Concentration & Absorbance at 230nm & Percent inhibition \\
\hline Control & $0.0901 \pm 0.0004$ & - \\
\hline Standard & $0.1791 \pm 0.0017$ & 89.21 \\
\hline 10 & $0.1341 \pm 0.0014$ & 33.27 \\
\hline 25 & $0.1421 \pm 0.0006$ & 37.25 \\
\hline 50 & $0.1329 \pm 0.0021$ & 49.12 \\
\hline 75 & $0.1247 \pm 0.0011$ & 57.41 \\
\hline 100 & $0.1135 \pm 0.0005$ & 64.57 \\
\hline
\end{tabular}

Table 3: By reducing power assay.

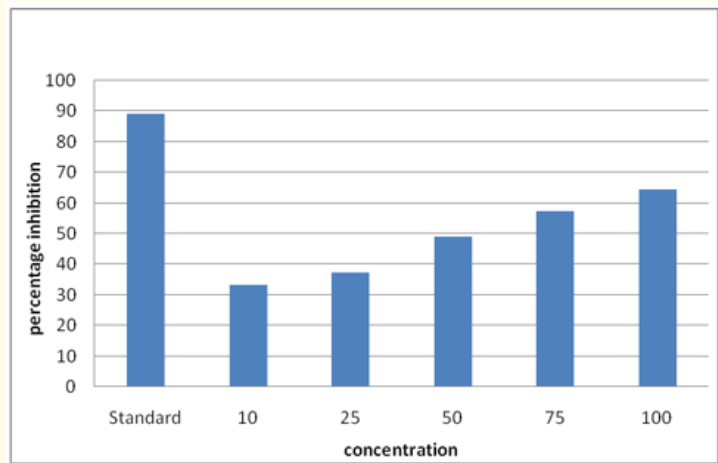

Figure 2

\section{Phosphomolebdenum method}

Total anti-oxidant capacity assay is a spectroscopic method for the quantitative determination of anti-oxidant capacity, through the formation of a phosphomolybdenum complex. The activity increased significantly with increasing concentration of the extract was given in table 4 and figure 3 . At 10, 25, 50, 75 and $100 \mu \mathrm{g} / \mathrm{ml}$ the Percent inhibition was 30.26, 36.54, 48.09, 56.39 and respectively.

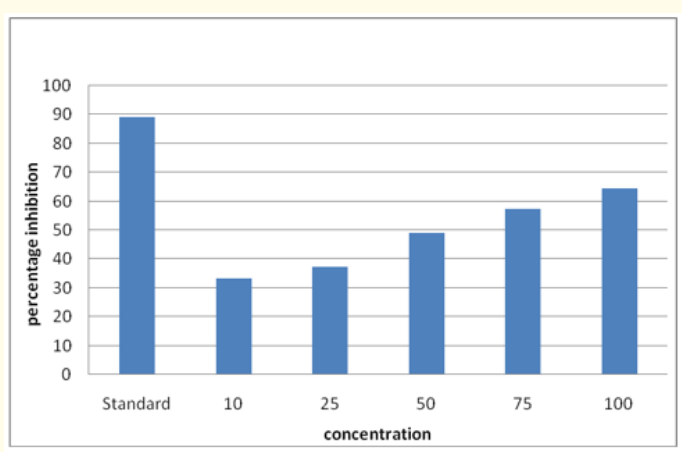

Figure 3

\begin{tabular}{|l|c|c|}
\hline Concentration & Absorbance at 230nm & Percent inhibition \\
\hline Control & $0.0814 \pm 0.0002$ & - \\
\hline Standard & $0.1781 \pm 0.0017$ & 89.21 \\
\hline 10 & $0.1261 \pm 0.0002$ & 33.27 \\
\hline 25 & $0.1640 \pm 0.0004$ & 37.25 \\
\hline 50 & $0.1518 \pm 0.0013$ & 49.12 \\
\hline 75 & $0.1331 \pm 0.0007$ & 57.41 \\
\hline 100 & $0.1460 \pm 0.0014$ & 64.57 \\
\hline
\end{tabular}

Table 4: Phosphomolebdenum method.

Phenolic compounds are known as powerful chain-breaking anti-oxidants, important plant constituents because of their scavenging ability due to their hydroxyl groups and contribute directly to antioxidative action. Phenolic compounds are also effective hydrogen donors, which makes them good anti-oxidant. It is suggested that polyphenolic compounds have inhibitory effects on mutagenesis and carcinogenesis in humans when ingested up to $1 \mathrm{gm}$ daily with a diet rich in fruits and vegetables [4,6,10-14].

\section{Conclusion}

The current study concludes that the ethanol extract of mansoa alliaceae leaves contains a considerable amount of flavonoids, and from this we conclude that mansoa alliaceae leaves have a high anti - oxidant activity. More bioactive compounds isolation would however help to determine their safety and effectiveness as a leading anti - oxidant nominee for pharmaceutical purposes.

\section{Acknowledgement}

Authors are sincerely thankful to V.V. Institute of Pharmaceutical Sciences, Gudlavalleru, India for providing necessary facilities for carryout the research work. Chalasani Sudhakar Rao is gratefully acknowledged for helping in the collection of the plant material.

\section{Bibliography}

1. World Health Organization. WHO technical report series. Geneva, Switzerland: WHO (2011).

2. Devang Pandya., et al. "Pharmacognostic and phytochemical evaluation of aerial parts of Bignonia Alliaceae". International Journal of Pharmacy and Life Sciences (IJPLS) 3.1 (2012): 1339-1344 1339.

3. Enriquez M., et al. "Antioxidant activity and differentiation of essential oils of Guaviduca (Piper carpunya L.) and Sacha Ajo (Mansoa alliacea L.)". Italian Journal of Food Science 31.5 (2008): 19-28. 
4. Govas Llamocca Jenny E., et al. "Sterols present in the apolar extract of garlic roots of garlic sacha Mansoa alliacea". Revista de la Sociedad Química del Perú 84.4 (2018): 513-521.

5. Maria das Graças Bichara Zoghbi., et al. "The genus Mansoa (Bignoniaceae): a source of organosulfur compounds". Brazilian Journal of Pharmacognosy 19.3 (2009).

6. Venkataraman Sowmyalakshmi and Srilakshmi Gunda. "Phytochemical constituents and pharmacological activities of Kigelia africana and Mansoa alliacea - a comprehensive review". Asian Journal of Pharmaceutical and Clinical Research 11 (2018): 29-32.

7. Jeng KCG and Hou RCW. "Sesamin and sesamolin: Nature's therapeutic lignans". Current Enzyme Inhibition 1 (2005): 1120.

8. Chandra P., et al. "Analgesic and anti-inflammatory activity of methanolic extract from Jatropha curcas leaves on experimental animals". Indian Drugs 50.8 (2013): 32-38.

9. Li H., et al. "Antioxidant activities of extracts and fractions from Lysimachia foenumgraecum Hance". Bioresource Technology 100.2 (2009): 970-974.

10. Harborne JB. Phytochemical methods: London Chapman and Hill Ltd. (1973): 49-188.

11. Gupta M., et al. "Anti-ulcerr activity of ethanol extract of Terminalia pallid Brandis in Swiss albino rats". Journal of Ethnopharmacology 97 (2005): 405- 408.

12. Keser S., et al. "Hydrogen peroxide radical scavenging and total anti-oxidant activity of Hawthorn". Journal of Chemistry 2.1 (2012): 9-12.

13. Arulpriya P., et al. "In-vitro anti-oxidant testing of the extracts of Samanea saman (Jacq.) Merr". Der Chemica Sinica 1.2 (2010): 73-79.

14. Prieto P., et al. "Spectrophotometric quantitation of anti-oxidant capacity through the formation of the phosphomolybdenum complex: specific application to the determination of vitamin E”. Analytical Biochemistry 269.2 (1999): 73-79.

15. Evans CA., et al. "Anti-oxidant properties of phenolic compounds". Trends in Plant Science 2 (1997): 152.

\section{Assets from publication with us}

- Prompt Acknowledgement after receiving the article

- Thorough Double blinded peer review

- Rapid Publication

- Issue of Publication Certificate

- High visibility of your Published work

Website: www.actascientific.com/

Submit Article: www.actascientific.com/submission.php

Email us: editor@actascientific.com

Contact us: +919182824667 